\title{
Geographies of violence.
}

\author{
BUTLER-WARKE, A.
}

2020 


\title{
Geographies of Violence, Marcus A. Doel. SAGE Publications Ltd, London (2017). vii and 223 pp., notes and index. $£ 25.99$ cloth, ISBN: 978-1-4739-3769-7.
}

\author{
Reviewed by Alice Butler-Warke, School of Applied Social Studies, Robert Gordon \\ University, Aberdeen, AB10 7AQ, UK.
}

Through Geographies of Violence, Marcus Doel, Professor of Human Geography at Swansea University, allows us to delve into a 'carnival of cannibalism' (2017: 5). His monograph is a veritable curiosity cabinet of violence and terror that permits readers to explore tales of horror in a lineage that is neither logical, nor causal, nor geographical, nor historical' (2017: 3). It is this montage approach that is the book's strength and weakness. Doel tells us that, through the text, he wants 'to hit you in the face and the stomach with the violence and horror that is you and your world', (2017: 2) meaning that the text follows a thematic lineage rather than a strict temporal lineage. That this is an uncomfortable, at times confused (and confusing) process, is perhaps part of the reader's uneasy journey through the text and the story of society's propensity to violence.

Touching on the autos-da-fé of the Portuguese Inquisition, British colonial massacres, the horrors of the Nazi death camps, the Napoleonic Wars, and the use of bioweapons, Doel takes us on a journey through the cruelty and violence of Western civilization. Yet, the book is more than a recounting of horrors. It is an account of the violence of the capitalist system. Doel overtly guides his readers to visit the violent and graphic examples of monarchs and elite forces exerting power over the lives of entire populations and the examples fulfil the Foucauldian notion of juridical power (Foucault, 1976). The true violence that Doel guides us towards is akin to the everyday biopolitical power that determines and constrains our every move (Foucault, 1976). For Doel, 'capitalism in its entirety is a slaughter industry' killing people, homes, animals, and land through creative destruction (2017: 82-3).

Doel's true skill comes through in his ability to gradually weave a clear and seemingly indisputable argument with the disparate threads he brings. The reader slowly realises that she is not an innocent bystander in Doel's argument around death and destruction but that she is complicit in the violence. Doel underscores the centrality of the quest for accumulation in the stories of violence. In chapter 3, Doel uses the example of King Leopold's Congo where imperial powers took hostage women, children and the elderly who they 'abused, starved and murdered' (2017: 40) while waiting for Congolese men to harvest rubber. Doel deftly connects the varied examples back into a Marxist argument whereby 'commodities are congealed masses of amorphous human labour' (2017: 40), highlighting the role of the human and corpse in the accumulation and production processes. The strength of this argument comes through in Doel's assertion that 'capital is a monstrous, artificial and undead life form that feeds off the slow release of the worker's energy, the draining of which is often strung out over a lifetime' (2017: 42).

Though the focus of the book is to be found in the subtext as much as in the overt examples of the geographies of violence, the snapshots Doel offers take us to various timescapes and landscapes. His most convincing examples come from his discussions of the atrocities committed by the Nazis in World War II. It is in these examples of the "murder machines" in the Konzentrationslager camps that the depth of the modern era's annihilation comes through in the lucidity of Doel's prose.

The book will be of interest to cultural geographers, sociologists, social psychologists, anthropologists and historians for its content and stylistic. Readers of Emotion, Space and Society will value Doel's work for its contribution to the debate on affective landscapes and the role of emotion in historical timescapes and geographical landscapes. The montage style of the book means that some chapters could stand alone and offer thematic insight into topics ranging from 'The Human Slaughter Industry' to 'Atmospheric Terrorism'. However, the book can better be appreciated as a whole, where the thread of the everyday violence of capitalism and the trauma of accumulation can weave its way through the chapters. The narrative reaches a biting conclusion in the final page of the book with Doel's acerbic attack on the 'allconsuming adventure of capitalism', 'the carnival of capitalism that has been so very kindly laid on by the powers that be' (2017: 174). It is this that we must take away from Doel's meanderings through violence 
and horror: for Doel, the capitalist power structure with the quest for accumulation at its core at once superficially entertains and amuses us, whilst slowly 'killing space and killing time' (2017: 174). We are, in Doel's reckoning part of this structure that seeks death and destruction, and we are complicit in its sedative and hypnotic effects.

\section{References}

M Foucault The Will to Knowledge: The History of Sexuality Volume 1 (1976) (trans. R Hurley, 1998) 